\title{
Effects of long-term treatment with melatonin or melatonin plus ectopic pituitary transplants on testicular LH/hCG and prolactin receptors in juvenile Syrian hamsters (Mesocricetus auratus)
}

\author{
A. G. Amador $\uparrow$, B. A. Richardson $\ddagger$, H. G. Klemcke§, M. K. Vaughan*, \\ R. W. Steger $\dagger$, A. Bartke $\dagger$ and R. J. Reiter*
}

Departments of Obstetrics \& Gynecology, and *Cellular \& Structural Biology, The University of Texas Health Science Center at San Antonio, San Antonio, Texas 78284-7762, U.S.A.

\begin{abstract}
Summary. Juvenile hamsters were injected daily with melatonin and some were also given transplants of 2 pituitaries under the kidney capsule. Weights of the testes and the accessory reproductive glands were reduced after 8 and after 12 weeks of melatonin treatment, but remained unaltered in animals treated with ectopic pituitary transplants. Levels of testicular $\mathrm{LH} / \mathrm{hCG}$ receptors were significantly reduced by daily melatonin injections for 8 and 12 weeks. The presence of pituitary transplants in melatonininjected hamsters prevented these reductions, and increased $\mathrm{LH} / \mathrm{hCG}$ receptors above control levels. These changes in testicular $\mathrm{LH} / \mathrm{hCG}$ receptors were closely related to alterations in serum prolactin concentration induced by melatonin and pituitary transplants. After 8 , but not after 12 weeks of treatment, testicular prolactin receptor levels were reduced by melatonin and maintained by the presence of pituitary transplants. We conclude that: (a) juvenile male hamsters become sensitive to the effects of daily melatonin injections when they reach maturity; (b) daily melatonin injections can reduce the levels of testicular $\mathrm{LH} / \mathrm{hCG}$ and prolactin receptors; and (c) the effects of melatonin on $\mathrm{LH} / \mathrm{hCG}$ and prolactin receptors are probably due to suppression of endogenous prolactin release.
\end{abstract}

\section{Introduction}

Under conditions of natural photoperiod, reproductive activity in the Syrian (golden) hamster is restricted to spring and summer. Gonadal involution takes place in early fall. Artificial maintenance of long photoperiods in the laboratory allows reproductive functions to continue throughout the year, but gonadal atrophy can be readily induced by transfer to short photoperiod, blinding or appropriately timed injections of a pineal product, melatonin (Gaston \& Menaker, 1967; Seibel \& Schweisthal, 1969; Reiter, 1973, 1980; Tamarkin et al., 1976). Testicular regression induced by short photoperiods is accompanied by a precipitous decline in the number of testicular $\mathrm{LH} / \mathrm{hCG}$ and prolactin receptors (Bex \& Bartke, 1977; Klemcke et al., 1983). These changes are thought to be due to suppression of plasma prolactin concentrations in short photoperiods because they can be mimicked by treatment with an inhibitor of prolactin release, bromocriptine, and reversed by

\footnotetext{
† Present address: Department of Physiology, School of Medicine, Southern Illinois University, Carbondale, IL 62901-4531, U.S.A.

¥ Present address: Department of Biology, University of Michigan-Flint, Flint, MI 48502, U.S.A.

$\S$ Present address: USDA, Roman L. Hruska, U.S. Meat Animal Research Center, Clay Center, NE 68933, U.S.A.
} 
injections of prolactin or by treatment with prolactin-secreting ectopic pituitary transplants (Bex \& Bartke, 1977; Klemcke et al., 1984). There is some evidence that endocrine changes induced by treatment with melatonin may not be completely equivalent to those produced by exposure to short photoperiods. We have demonstrated that the decrease in the weight of the testes and the accessory reproductive glands induced by daily melatonin injections can be completely prevented by transplantation of two homologous pituitaries under the renal capsule (Richardson et al., 1982). This procedure is only partly effective in preventing regression of the male reproductive system in animals subjected to short photoperiods or blinding (Matthews et al., 1978; Bartke et al., 1980a).

In the present study, we examined the time course of changes in testicular $\mathrm{LH} / \mathrm{hCG}$ receptors in juvenile Syrian hamsters during a 12-week period of daily melatonin injections with and without concomitant treatment with ectopic pituitary transplants. We also measured testicular prolactin receptors after 8 and after 12 weeks of these treatments. Weight of the testes and the accessory reproductive glands, serum and pituitary concentrations of prolactin, LH and FSH and serum concentrations of testosterone were monitored throughout the study.

\section{Materials and Methods}

Juvenile Syrian hamsters ( $\sim 45$ days old) were purchased from Engle (Farmersburg, IN). They were maintained in groups of 45 animals per clear plastic cage in a windowless and environmentally controlled room $\left(22 \pm 2^{\circ} \mathrm{C}\right.$ ). The animals were exposed to light (fluorescent; Sylvania Super Saver 35; 150-300 foot candles; 1615-3230 lx) daily from 06:00 to 20:00 h (14L:10D). All hamsters received Wayne Lab Blox and tap water ad libitum. Some of the hamsters received two homologous anterior pituitary grafts beneath the capsule of the left kidney. Pituitary transplants were from male hamsters of the same age. Surgery was carried out with the animals under ether anaesthesia. Melatonin was obtained from Sigma Chemical Co. (St Louis, MO) and was prepared in ethanolic saline $(1: 90, \mathrm{v} / \mathrm{v})$ every day before its injection at 16:00 $\mathrm{h}$. The injections were subcutaneous at the back of the neck region in a volume of $0 \cdot 1 \mathrm{ml}$ and the daily dose was $25 \mu \mathrm{g}$ melatonin/animal.

Eight hamsters were killed before the start of treatments and the remaining animals were divided into the following experimental groups: (1) controls, (2) daily melatonin injections and (3) daily melatonin injections and two anterior pituitary homografts. Controls received daily injections of ethanolic saline. Animals were treated for 1,2, 3, 6, 8 or 12 weeks, at which time they were killed by decapitation. Trunk blood was collected into heparinized tubes. Testicular, accessory sex organ (seminal vesicles plus coagulating glands) and anterior pituitary weights were recorded. The testes were decapsulated, placed in polypropylene tubes, rapidly frozen in a solid $\mathrm{CO}_{2}$ /acetone mixture, and stored at $-70^{\circ} \mathrm{C}$ until assayed for $\mathrm{LH} / \mathrm{hCG}$ and prolactin receptors. Serum samples and pituitaries were stored at $-20^{\circ} \mathrm{C}$ until assayed for hormone concentrations.

Measurement of $\mathrm{LH} / \mathrm{hCG}$ and prolactin receptors was done by radioreceptor assay as reported previously (Klemcke et al., 1981, 1984). Specific activities of ${ }^{125}$ I-labelled prolactin (NIH-P-S-13) and ${ }^{125} \mathrm{I}$-labelled hCG (CR $\left.121 ; \mathrm{NIH}\right)$ were 15 and $68 \mu \mathrm{Ci} / \mu \mathrm{g}$, respectively, with respective maximal binding abilities of 63 and $45 \%$. Protein content of each testis sample was determined using a previously validated (Klemcke et al., 1981) modification of the Lowry procedure (Markwell et al., 1978) and BSA as a standard.

Immunoreactive $\mathrm{LH}$ and FSH concentrations were determined by RIA utilizing reagents supplied by the National Hormone and Pituitary Program, NIH. Results were expressed in terms of NIAMDD purified rat hormone preparations. Prolactin concentrations were also measured using materials supplied by the NIH. Because of the lack of parallelism between rat and hamster inhibition curves, the prolactin results were expressed with reference to a pool of standard hamster anterior pituitaries (SHAP; Donofrio et al., 1973/74). Serum testosterone concentrations were measured using a kit from Diagnostic Products (Los Angeles, CA). Samples were assayed at the end of the experiment in a single assay. The average values of sensitivity and intra-assay coefficients 
of variation were: $\mathrm{LH}-1.1 \mathrm{ng} / \mathrm{ml}, 7.6 \% ; \mathrm{FSH}-13.8 \mathrm{ng} / \mathrm{ml}, 12.8 \%$; prolactin $-150 \mathrm{ng} \mathrm{SHAP} / \mathrm{ml}$, $7.6 \%$; and testosterone $-0.2 \mathrm{ng} / \mathrm{ml}, 5 \%$, respectively.

Data were analysed by analysis of variance followed by the Student-Newman-Keuls test for differences amongst multiple means. Data were examined for homogeneity of variance using Bartlett's test and for normality of distribution using the Kolmogorov-Smirnov test. Mathematical transformations were made when necessary (Sokal \& Rohlf, 1981; Schefler, 1984).

\section{Results}

\section{Testicular $L H / h C G$ and prolactin receptor levels}

Both the concentration and total content of $\mathrm{LH} / \mathrm{hCG}$ receptors in the testes were significantly reduced after 8 and after 12 weeks of daily melatonin injections (Group 2) as compared to vehicleinjected controls (Group 1). However, values in Group 2 hamsters did not differ from those of pretreatment controls (Fig. la, b). In animals in Group 3 (pituitary transplants and melatonin), the content and concentration of testicular $\mathrm{LH} / \mathrm{hCG}$ receptors were significantly higher than those in Group 2 animals at all times between 2 and 12 weeks. LH/hCG receptor levels in animals in Group 3 were also significantly higher than those in Group 1 animals throughout most of the study period. In addition, after the first week of treatment, the concentration of testicular $\mathrm{LH} / \mathrm{hCG}$ receptors was significantly lower in animals in Group 2 than in those in the remaining two groups.

Concentration and total content of testicular prolactin receptors were reduced significantly in Group 2 animals after 8 weeks of treatment, and this reduction was completely reversed by the presence of pituitary transplants (Group 3, Table 1). After 12 weeks of treatment, melatonin had no effect on levels of prolactin receptors. However, pituitary transplants (Group 3) increased total content to quantities above those in Group 1 or $2(P<0.05)$.

\section{Hormone concentrations}

Throughout the period of treatment, serum prolactin concentrations were about $25 \%$ lower in Group 2 than in Group 1 hamsters (Fig. 1c). Although this difference was consistently observed, the apparent decrease was not significant at any time, and melatonin did not reduce serum prolactin values as compared with those of pre-treatment controls $(P<0.05)$. Transplantation of two pituitary glands under the renal capsule in melatonin-treated hamsters (Group 3) elevated serum prolactin concentrations at all times $(P<0.05)$.

Serum concentrations of testosterone in control hamsters fluctuated widely throughout the experimental period (Fig. 1d) but, except for the increase at 1 week $(P<0.05)$, did not significantly differ $(P<0.05)$ from pre-treatment values. Throughout most of the treatment period there was a trend towards a decrease in serum testosterone in Group 2 hamsters, but none of these apparent differences was statistically significant. Serum concentration of LH and FSH exhibited no significant treatment effects except for an increase $(P<0.05)$ in serum FSH values in Group 3 hamsters after 12 weeks (data not shown).

Pituitary prolactin content was reduced $(P<0.05)$ and pituitary FSH content increased $(P<0.05)$ after 12 weeks of treatment with melatonin (Group 2). Pituitary transplants appeared to cause an increase in pituitary gonadotrophin content after 6,8 and 12 weeks, but only the effect on LH was statistically significant (data not shown).

\section{Body and organ weights}

Absolute testicular weight was significantly lower in Group 2 than in Group 1 hamsters, starting after 6 weeks of treatment (Fig. 1e). Relative (to body weight) testicular weight declined gradually, but significant differences with controls appeared only after 8 weeks of treatment (data not 

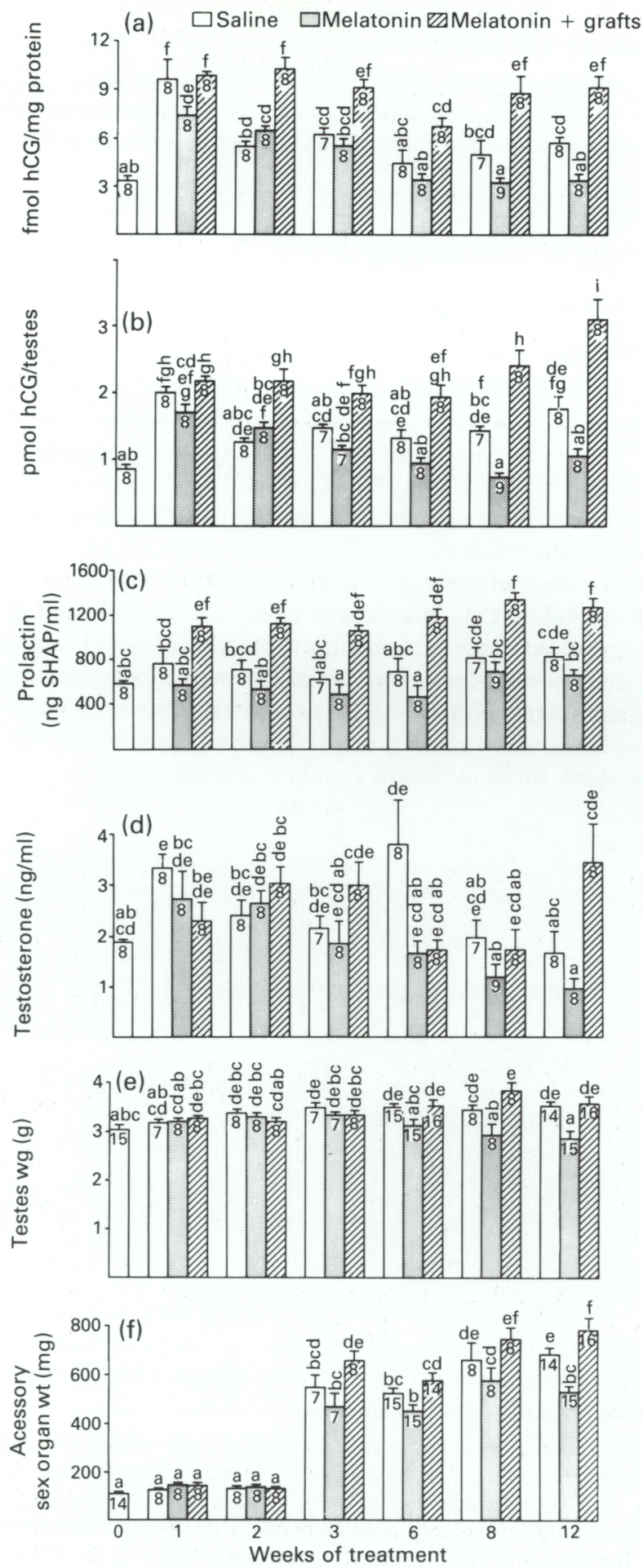
Table 1. Effects of treatment with daily melatonin injections (Group

2) or melatonin plus two ectopic pituitary homografts (Group 3) on the concentration and total content of prolactin receptors in the testes of juvenile hamsters

\begin{tabular}{lccc}
\hline & & \multicolumn{2}{c}{ Prolactin receptors } \\
\cline { 3 - 4 } Treatment & $\begin{array}{c}\text { No. of } \\
\text { hamsters }\end{array}$ & fmol/mg protein & fmol/testes \\
\hline 8 weeks & & & \\
$\quad$ Group 1 (controls) & 7 & $28 \cdot 5 \pm 4 \cdot 4^{\mathrm{b}}$ & $1258 \pm 146^{\mathrm{a}, \mathrm{b}}$ \\
$\quad$ Group 2 & 9 & $14 \cdot 4 \pm 2 \cdot 6^{\mathrm{a}}$ & $626 \pm 127^{\mathrm{c}}$ \\
$\quad$ Group 3 & 8 & $27 \cdot 4 \pm 3 \cdot 2^{\mathrm{b}}$ & $1631 \pm 138^{\mathrm{a}}$ \\
12 weeks & 8 & $23 \cdot 1 \pm 2 \cdot 8^{\mathrm{b}}$ & $1050 \pm 136^{\mathrm{b}}$ \\
$\quad$ Group 1 (controls) & 8 & $23 \cdot 0 \pm 4 \cdot 7^{\mathrm{b}}$ & $897 \pm 317^{\mathrm{b}, \mathrm{c}}$ \\
$\quad$ Group 2 & 8 & $30 \cdot 1 \pm 2 \cdot 8^{\mathrm{b}}$ & $1529 \pm 140^{\mathrm{a}}$ \\
\hline Group 3 & & &
\end{tabular}

Values are mean \pm s.e.m.

Values with different superscripts are significantly different, $P<0 \cdot 05$.

shown). Absolute and relative weights of accessory sex glands were decreased in Group 2 hamsters after 12 and 8 weeks of treatment, respectively (Fig. 1f). Concomitant treatment with pituitary transplants (Group 3) prevented these effects of melatonin treatment (Fig. 1e, f). After 12 weeks of treatment anterior pituitary weight and body weight were significantly greater in melatonin-treated animals (Group 2) than in controls (Group 1: $P<0.05$; data not shown).

\section{Discussion}

The main findings of the present study were that daily melatonin injections caused significant reduction in the number of $\mathrm{LH} / \mathrm{hCG}$ receptors in the testes of Syrian hamsters and that ectopic pituitary transplants increased testicular content of $\mathrm{LH} / \mathrm{hCG}$ receptors in melatonin-treated animals.

A decrease in the concentration and total content of prolactin receptors in the testes was detected after 8 weeks of daily treatment with melatonin and an increase in testicular prolactin receptors after treatment with both melatonin and pituitary transplants. The relative magnitude of treatment effects on testicular $\mathrm{LH} / \mathrm{hCG}$ and prolactin receptors agrees with previous data (Klemcke et al., 1984; Amador et al., 1985) which indicate that testicular LH/hCG receptors are much more responsive to modification of serum prolactin than are prolactin receptors. These observations probably reflect the contribution of an as-yet-unidentified hormone(s) to the regulation of testicular prolactin receptors. We have no explanation for the normal levels of prolactin receptors after 12 weeks of melatonin treatment in spite of continued suppression of serum prolactin concentrations. Perhaps prolactin receptors can eventually develop in the presence of modestly, although significantly, reduced peripheral prolactin concentration.

Fig. 1. Testicular $\mathrm{LH} / \mathrm{hCG}$ receptor concentration (a) and content (b), concentrations of prolactin (c) and testosterone (d) and weights of testes (e) and accessory sex glands (seminal vesicles plus coagulating glands) (f) as a function of duration of treatment with melatonin (Group 2) or melatonin plus two pituitary transplants (Group 3) in juvenile Syrian hamsters. Values are mean \pm s.e.m., for the number of hamsters indicated. Values with a letter in common are not significantly different from each other $(P>0.05)$. 
The possibility of a direct effect of melatonin either in vivo on the receptors or in vitro on receptor measurement is an unlikely explanation for these observations. Identical doses of melatonin were administered to animals given melatonin alone and to those given melatonin plus pituitary transplants, yet receptor levels were reduced in the former group and increased in the latter. Furthermore, in-vitro incubation of Syrian hamster testes in the presence of melatonin or other indoleamines did not alter $\mathrm{LH} / \mathrm{hCG}$ receptor levels, or hCG-stimulated steroidogenesis (Cutty et al., 1981; Jarriage et al., 1984; A. G. Amador \& A. Bartke, unpublished data). Ellis (1972) reported that melatonin and serotonin inhibited the in-vitro biotransformation of progesterone (17 $\alpha$-progesterone), and androstenedione to testosterone in testicular minced and microsomal preparations. However, those studies were done in rats at non-physiological temperatures $\left(37^{\circ} \mathrm{C}\right)$ and using phosphate buffer, whereas our studies were performed in hamsters at physiological temperatures $\left(32^{\circ} \mathrm{C}\right)$ and using Krebs-Ringer. Also, they do not analyse the effect of melatonin on gonadotrophin-stimulated steroidogenesis. Although, there is evidence for testicular melatonin receptors in rodents (Lang et al., 1981), this and the previously mentioned report (Ellis, 1972) do not imply that melatonin has to affect $\mathrm{LH} / \mathrm{hCG}$ receptors. Therefore, the direct effects of melatonin on testicular function would be at $\mathrm{LH} / \mathrm{hCG}$ receptor-independent sites.

In the present study, we did not attempt to identify the mechanisms responsible for depletion of testicular $\mathrm{LH} / \mathrm{hCG}$ and prolactin receptors by melatonin. However, our data strongly suggest that these effects of melatonin were due, at least in part, to inhibition of endogenous prolactin release. Prolactin-secreting pituitary transplants completely reversed the melatonin effects. Moreover, changes in serum prolactin concentrations in animals treated with melatonin or melatonin plus pituitary transplants correlated very closely with changes in the concentration and content of $\mathrm{LH} / \mathrm{hCG}$ receptors in the testes throughout the study. In further support of the role of prolactin in mediating the effects of injected melatonin on testicular hormone binding, treatment with melatonin caused no consistent changes in the concentrations of LH and FSH, adenohypophysial hormones capable of regulating testicular $\mathrm{LH} / \mathrm{hCG}$ receptors. This hypothesis is also consistent with our demonstration that suppression of endogenous prolactin release in the hamster by treatment with bromocriptine is associated with loss of $\mathrm{LH} / \mathrm{hCG}$ and prolactin receptors from the testes and that these changes can be completely prevented by concurrent treatment with ovine prolactin (Klemcke et al., 1984).

On the basis of an earlier study (Richardson et al., 1982), it could be anticipated that treatment with melatonin injections would cause a precipitous fall in serum testosterone values and major reductions in testicular and accessory sex gland weights. However, the effects of melatonin on these measurements in the present study were modest. Sisk \& Turek (1983a, b) showed that, in Syrian hamsters raised in short photoperiod since birth, testicular regression does not occur until after the animals have undergone sexual maturation and achieved a testicular size identical to that observed in hamsters raised in long photoperiod. Only after this increase in testicular weight does photoperiod-related regression of the testes in these animals start (around 10 weeks of age). In bank voles exposed to a short photoperiod after weaning, the puberty-related increase in testes weight and $\mathrm{LH} / \mathrm{hCG}$ receptor number is inhibited (Tähkä \& Rajaniemi, 1985). Afterwards, full testicular regression follows. The present results demonstrate that melatonin-induced changes in testicular function, like those induced by photoperiod, can occur only after the Syrian hamster has reached sexual maturity. Furthermore, in Syrian hamsters injected for 17 days with bromocriptine, starting at Day 14 of age, testicular $\mathrm{LH} / \mathrm{hCG}$ receptor concentration was unchanged, although the total content of $\mathrm{LH} / \mathrm{hCG}$ receptors was decreased because of the reduced testicular weight (Klemcke et al., 1984). The present results therefore represent a description of melatonin effects during early stages of the development of responsiveness of the pituitary-testicular axis to exogenous melatonin. Importantly, there was no hint of even the slightest reduction of testicular and accessory sex gland weights in animals given ectopic pituitary transplants in addition to melatonin.

On the basis of these observations, we suggest that suppression of endogenous prolactin release leading to the loss of testicular $\mathrm{LH} / \mathrm{hCG}$ and prolactin receptors represents one of the mechanisms 
by which melatonin treatment can suppress testicular activity in Syrian hamsters. The reduction in $\mathrm{LH} / \mathrm{hCG}$ receptor levels in the testis is particularly significant in that it provides a possible explanation for the previously demonstrated ability of melatonin to suppress serum testosterone concentrations without altering serum LH concentration (Richardson et al., 1982).

The evidence that loss of testicular hormonal receptors represents one of the earliest detectable responses to both short photoperiod (Bartke et al., 1980b; Klemcke et al., 1983) and exogenous melatonin treatment gives a further, although indirect, indication that changes in testicular receptors for adenohypophysial hormones may be one of the mechanisms responsible for seasonal loss and recovery of gonadal activity.

These studies were supported by NIH and NSF through grants HD 2001, HD 20033 (A.B.), PCM 8304706 (R.J.R.) and NIH Post-doctoral Fellowship F32 ND05900 (B.A.R.). We thank the National Hormone and Pituitary Program and Dr R. Canfield and Dr A. F. Parlow for materials used in receptor and hormone assays; Ms M. P. Hogan for excellent assistance; and Ms S. Huegele, Ms Toni Gower, and Ms G. Small for help in preparing the manuscript.

\section{References}

Amador, A., Klemcke, H.G., Bartke, A., Soares, M.J., Siler-Khodr, T.M. \& Talamantes, F. (1985) Effects of different numbers of ectopic pituitary transplants on regulation of testicular $\mathrm{LH} / \mathrm{hCG}$ and prolactin receptors in the hamster (Mesocricetus auratus). J. Reprod. Fert. 73, 483-489.

Bartke, A., Goldman, B.D., Bex, F.J., Kelch, R.P., Smith, M.S., Dalterio, S. \& Doherty, P.C. (1980a) Effects of prolactin on testicular regression and recrudescence in the golden hamster. Endocrinology 106, 167-172.

Bartke, A., Goldman, B.D., Klemcke, H.G., Bex, F.J. \& Amador, A.G. (1980b) Effects of photoperiod on pituitary and testicular function in seasonally breeding species. In Functional Correlates of Hormone Receptors in Reproduction, pp. 171-185. Eds V. B. Mahesh, T. G. Muldoon, B. B. Saxena \& W. A. Sadler. Elsevier/North Holland, New York.

Bex, F.J. \& Bartke, A. (1977) Testicular LH binding in the hamster: modification by photoperiod and prolactin. Endocrinology 100, 1223-1226.

Cutty, G.B., Goldman, B.D., Doherty, P. \& Bartke, A. (1981) Melatonin prevents decrease in plasma PRL and $\mathrm{LH}$ levels in male hamsters exposed to a short photoperiod. Int. J. Androl. 4, 281-290.

Donofrio, R.J., Reiter, R.J., Sorrentino, S., Jr, Blask, D.E. \& Talbot, J.E. (1973/74) A method for measurement of prolactin in the hamster by means of radioimmunoassay. Neuroendocrinology 13, 79-92.

Ellis, L.C. (1972) Inhibition of rat testicular androgen synthesis in vitro by melatonin and serotonin. Endocrinology 90, 17-28.

Gaston, S. \& Menaker, M. (1967) Photoperiodic control of hamster testis. Science, N.Y. 158, 925-928.

Jarrige, J.-F., Thieblot, P. \& Boucher, O. (1984) Lack of melatonin action on testosterone production by superfused rat interstitial cells. Acta endocr., Copenh. 107, 117-124.

Klemcke, H.G., Bartke, A. \& Goldman, B.D. (1981) Plasma prolactin concentrations and testicular human chorionic gonadotropin binding sites during short photoperiod-induced testicular regression and recrudescence in the golden hamster. Biol. Reprod. 25, 536-548.

Klemcke, H.G., Bartke, A. \& Borer, K.T. (1983) Testicular prolactin receptors and serum growth hormone in golden hamsters: effects of photoperiod and time of day. Biol. Reprod. 29, 605-614.

Klemcke, H.G., Bartke, A. \& Borer, K.T. (1984) Regulation of testicular prolactin and luteinizing hormone receptors in golden hamsters. Endocrinology 114, 594-604.

Lang, U., Aubert, M.L. \& Sizonenko, P.C. (1981) Tissue distribution and subcellular location of melatonin receptors in the male rat. Experientia 37, 613.

Markwell, M.K., Haas, S.M., Bieber, L.L. \& Tolbert, N.E. (1978) A modification of the Lowry procedure to simplify protein determination in membrane and lipoprotein samples. Analyt. Biochem. 87, 206-210.

Matthews, M.J., Benson, B. \& Richardson, D.L. (1978) Partial maintenance of testes and accessory organs in blinded hamsters by homoplastic anterior pituitary grafts or exogenous prolactin. Life Sci. 23, 1131-1137.

Reiter, R.J. (1973) Comparative physiology: pineal gland. Ann. Rev. Physiol. 35, 305-328.

Reiter, R.J. (1980) The pineal and its hormones in the control of reproduction in mammals. Endocr. Rev. 1, 109-131.

Richardson, B.A., Petterborg, L.J., Vaughan, M.K., King, T.S. \& Reiter, R.J. (1982) The effect of twice daily gonadotropin-releasing hormone $(\mathrm{GnRH})$ administration and/or renal pituitary homografts on melatonin-induced gonadal atrophy in male Syrian hamsters. In The Pineal and its Hormones, pp. 129-142. Ed. R. J. Reiter, Alan R, Liss, Inc., New York.

Schefler, W.C. (1984) Statistics for Health Professionals. Addison-Wesley Publishing Co., Reading.

Seibel, H.R. \& Schweisthal, M.R. (1969) Relationships between the pineal gland and the gonads of single and 
parabiosed golden hamsters. J. Reprod. Fert. 18, 179, abstr.

Sisk, C.L. \& Turek, F.W. (1983a) Developmental time course of pubertal and photoperiodic changes in testosterone negative feedback on gonadotropin secretion in the Golden hamster. Endocrinology 112, $1208-1216$.

Sisk, C.L. \& Turek, F.W. (1983b) Gonadal growth and gonadal hormones do not participate in the development of responsiveness to photoperiod in the Golden hamster. Biol. Reprod. 29, 439-445.

Sokal, R.R. \& Rohlf, F.J. (1981) Biometry, 2nd edn. W. H. Freeman and Co., San Francisco.
Tähkä, K. M. \& Rajaniemi, H. (1985) Photoperiodic modulation of testicular LH receptors in the bank vole (Clethrionomys glareolus). J. Reprod. Fert. 75, 513-519.

Tamarkin, L., Westrom, W.K., Hamill, A.I. \& Goldman, B.D. (1976) Effect of melatonin on the reproductive systems of male and female hamsters: a diurnal rhythm in sensitivity to melatonin. Endocrinology 99, 1534-1541.

Received 7 March 1986 